\title{
Income Inequality in Indonesia: Panel Data of 34 Provinces 2014-2016
}

\author{
Mohammad Rofiuddin ${ }^{1, *}$, Firmansyah $^{1}$ \\ ${ }^{1}$ The authors are lecturers at the Universitas Diponegoro, Semarang, Indonesia
}

\begin{abstract}
Income inequality is the difference in the ability of people to have goods or services, and more broadly, it is the problem of community welfare. Income inequality can be measured at regional, national and global level. Income inequality in Indonesia,, which representing by Gini index, is still relatively high, even though the number tends to decline. The high level of income inequality is influenced by various factors. This study aims to analyze the influence of economic growth, population and provincial minimum wage toward income inequality in Indonesia. By applying a fixed-effect of panel data regression model of the 34 provinces along 2014-2016, the study finds that economic growth and population do not affect the income inequality, while provincial minimum wage has the negative effect.
\end{abstract}

Keywords: Income Inequality, Economic Growth, Minimum Wage, Population, Panel Data

\section{Introduction}

Indonesia's environment consist of thousand island scattered over both sides of the equator. Indonesia's also has large and growning population make rapid industrialisation. It present serious issues starting from inequalities on development industrialisation until it affect to environment. In the other way that also show how inequality does exist especially in economic aspect, because the industrialisation have not distributed well and that also impact environment.

Inequality of income distribution is at the core of all development issues and is a key development policy objective in many countries[1]. Income inequality is also driven by ability, human capital, discrimination, preference, market forces and fortune and connection[2]. The difference in income level can be found in any country or region based on the rich, poor and the middle class. Due to uneven of income, there is an inequality that varies from country to country or region to another.

Income inequality and poverty are two things that are being intensively pressured of its growth by the government. Inequality is closely related to poverty because it is fundamentally a relative poverty of indicator, namely the gap between the group of the rich and poor. The low of inequality, or the even distribution of income, is certainly one of the most important agendas of economic development[1].

Figure 1 shows the condition of income inequality occurred in Indonesia. The data also reflects the condition in the provincial level. Where each region would avoid extreme inequality. According to ${ }^{1}$, the high impacts of inequality can be divided as follows: 1) an extreme income inequality that causes inefficiency of economic; 2) an extreme income disparities that weaken the stability of social and solidarity; 3) an extreme inequality which is generally considered unfair. Income inequality can be a serious problem, due to the differences of economic growth across provinces. In addition, the number of population and the level of minimum wages also indicate a very substantial differences across the regions.

The study is concerning on income inequality and economic growth has been carried out by many scientists and other organizations. Based on the result of the literature review of[3] found that (i) Growth has a positive impact on inequality; (ii) Growth has a negative impact on inequality; and (iii) There is no relationship between growth and inequality. Regardless from the existing literature on income inequality and economic growth, there is still disagreement concerning on the impact of the economic growth toward the income inequality.

Shahbaz[4] ; Shahbaz, et al[5] ; Arifianto \& Setiyono[6] ; Rubin \& Segal[7] ; Adipuryanti \& Sudibi[8] ; Pauzi \& Budiana[9] , found that economic growth has a positive and significant influence toward the inequality of income distribution. While[10] shows that economic growth has a negative influence to the income inequality.

In addition to the economic growth other factors presumed has an influence toward the income inequality namely the total population. Which is the increasing of population will create the competition to gain employment becomes more stringent. The offering of laborers are greater than the demand of the laborers will create lower class of worker will be paid under the standard. This is as an impact on the higher rate of inequality[10] .

Sylwester[11] ; Bantika, et al[10] ; shown that the total population has a positive influence toward the income inequality. While[8], found that the number of employed population has no significant effect toward the inequality of income distribution.

Another factor that presumable has an influence to the inequality is minimum wages. 
Minimum wages is a useful policy to ensure that workers earn reasonable wages while preventing poverty in workers who are obedient to the fulfillment of reasonable living standards. Furthermore, income redistribution of the worker on the lowest pay scale reduces dispersion of wages and is likely to increase aggregate demand through multiplier effects. Minimum wage has been believed to be an effective means to reduce the income gap (Sungkar, et all[12] ; Lin \& Yun[13] ). The increasing of minimum wages is to be expected to increase revenues for millions of low-wages workers and thereby will reduce income inequality. Meanwhile, there is no consensus in the existing literature of industrialized countries on whether increasing the minimum wages has assisted lower the income inequality[13] .

Sungkar, et al[12], indicates that the minimum wages has a significant positive relationship, while[14], found that the increasing of minimum wages could cause the decreasing of income inequality through the minimum wages exceeds the value of maximum effectiveness (turning point). Lin \& Yun[13], found that the increasing of minimum wages reduce the inequality.

Based on the empirical studies have been performed, it was found the different results between the relationship of economic growth, total population and minimum wages toward income inequality. This research aims to analysis the determinants of income inequality at the provincial level in Indonesia.

\section{Methodology}

The method of data analysis in this research is using model of panel data regression analysis ${ }^{15}$. Meanwhile, the analysis approach used Fixed Effect Model (FEM). The empirical model is as follows:

$G I_{i t}=\alpha_{0}+B_{I} G R O W T H_{I T}+B_{2} P O P_{I T}+B_{3} W A G E S_{I T}+u_{i t}$ $G I$ is the income inequality in each of the province, GROWTH describes economic growth in each of the province. As well as $P O P$ and WAGES that are describes the total population and minimum wages in each of the provinces.

This research uses panel data with time period from 2014 to 2016 across 34 provinces. The source of the data is Statistics Indonesia[16] (Badan Pusat Statistik-BPS). Definition of variables are as follows; 1)Income inequality (GI) is the description of the distribution of community income of a region (area) in a certain period (time). The approach used is Gini index in each of province; 2) Economic growth (GROWTH) is the growth of production of goods and services in an economic region within a certain time interval expressed in percentage units; 3) Population (POP) is all persons domiciled in the geographical area of the Republic of Indonesia for 6 months or more and/or those who are domiciled for less than 6 months but aim to stay. The approach used is the number of the poor expressed in terms of inhabitant; 4) Provincial minimum wages (WAGES) is the minimum wage applicable to all districts/cities in one province expressed in Rupiah.

\section{Discussion}

Summary of statistic provides an overview of data profile used in this research.

Table 1 . Summary of statistic

\begin{tabular}{|l|c|c|c|c|}
\hline & $\begin{array}{c}\text { Inequalitie } \\
\text { s }\end{array}$ & $\begin{array}{c}\text { Grow } \\
\text { th }\end{array}$ & $\begin{array}{c}\text { Popul } \\
\text { ation }\end{array}$ & Min_Wage \\
\hline $\begin{array}{c}\mathrm{M} \\
\text { ean }\end{array}$ & 0.367 & 5.53 & 823. & 1716166 \\
1 & 98 & \\
\hline $\mathrm{M}$ & 0.362 & $\begin{array}{c}5.34 \\
0\end{array}$ & $\begin{array}{c}372 . \\
590\end{array}$ & 1705000 \\
$\mathrm{e}$ & & & & \\
$\mathrm{d}$ & & & & \\
\hline & 0.459 & 21.7 & 4775 & 3100000 \\
$\mathrm{M}$ & & 70 & .970 & \\
$\mathrm{a}$ & & & & \\
$\mathrm{X}$ & & & & \\
\hline & 0,275000 & $-1,21$ & 40,9 & 910000,0 \\
$\mathrm{M}$ & & & 3000 & \\
in & & & & \\
\hline
\end{tabular}

Table 2. Estimation Results Using Fixed Effect Model

\begin{tabular}{|c|c|}
\hline Variable & Coefficient \\
\hline $\mathrm{X}_{1}$ & $\begin{array}{c}-5,23 \mathrm{E}-06 \\
(-0,004408)\end{array}$ \\
\hline $\mathrm{X}_{2}$ & $\begin{array}{c}-2,02 \mathrm{E}-05 \\
(-0,327853)\end{array}$ \\
\hline $\mathrm{X}_{3}$ & $-4,21 \mathrm{E}-08^{* *}$ \\
& $(-3,898757)$ \\
\hline $\mathrm{C}$ & 0,456126 \\
& $(7,785004)$ \\
\hline R-squared & 0,842151 \\
\hline Adj. R-squared & 0,754727 \\
\hline F-statistic & 9,63295 \\
\hline Prob(F) & 0.0000 \\
\hline $\mathrm{N}$ & 102 \\
\hline
\end{tabular}

$$
\begin{array}{r}
\text { Note: } * \text { Significant at the level } 0,01 ; \\
* * \text { Significant at the level } 0,05 ; \\
* * * \text { Significant at the level } 0,1 .
\end{array}
$$

Results of the analysis indicated that economic growth is not significant toward the income inequality. It means that the increasing of economic growth cannot affect the increasing or decreasing of the income inequality in each of province in Indonesia. Empirically this result is contrary to the research conducted by Shahbaz [4]; Shahbaz, et al[5]; Arifianto \& Setiyono[6]; Rubin \& Segal[7]; Adipuryanti \& Sudibi[8]; Pauzi \& Budiana[9]; that indicates there is an influence of economic growth towards the income inequality. As well as Bantika, et al[10] shows that the economic growth has a negative influence towards the income inequality. Other factors that allow economic growth do not affect the income inequality due to most of capital in each province is only owned by a handful of people. Moreover, it is possible due to economic growth is not dynamically distributed in each of province.

The population based on the results of this research has no influence toward the inequality. This finding is in line with Adipuryanti \& Sudibi[8] ; found that the total population has no significant influence 
toward the inequality of income distribution. It means that the increasing occurs in the total population has no influence to the decreasing or the increasing of the income inequality. This is due to of each region dominantly is still able to accommodate the growth of population.

The provincial minimum wages based on this research has a negative influence toward the income inequality. This finding is in line with Litwin[14] ; Lin $\&$ Yun[13] found that the increasing of the minimum wages would reduce inequality. It means that the increasing of the minimum wages occurs in each of province will reduce the income inequality. This occurs due to the increasing of minimum wages of worker able to increase income. In turn, the distribution of income is possibility to provide multiplier effect.

\section{Conclusion}

Based on the results of the research shows economic growth and total population has no influence toward the income inequality. Meanwhile the provincial minimum wages has a negative influence toward the income inequality, this is due to wages is to be expected able to increase the income and in its distribution, its possibility will increase the demand of aggregate through its multiplier effect.

\section{References}

1. M. P. Todaro and S. C. Smith, "Economic Development. Eleventh Edition", Addison Wesley, United States (2011).

2. P. Kurniawan, and M. K. S. Budhi, "Pengantar Ekonomi Mikro dan Makro", Andi Offset, Yogyakarta (2015).

3. M. Y. Mawar, J. M. Mahyideen, and R. Saidon, "Economic Growth and Income Inequality, Proceeding of the $2^{\text {nd }}$ International Conference on Management and Muamalah $2015\left(2^{\text {nd }}\right.$ ICoMM) $16^{\text {th }}-17^{\text {th }}$ November 2015 " $(2015)$.

4. M. Shahbaz, "Income inequality-economic growth and non-linearity: a case of Pakistan", International Journal of Social Economics, 37(8), 613-636 (2010).

5. M. Shahbaz, F. Islam, and M. S. Butt, "Devaluation and income inequality: evidence from Pakistan", Munich Personal REPEC Archive (2011).

6. W. Arifianto and I. Setiyono, "Pengaruh Pertumbuhan Ekonomi Terhadap Distribusi Pendapatan Di Indonesia", Jurnal Pendidikan Ekonomi (JUPE), 1(3) (2013).

7. A. Rubin and D. Segal, "The effects of economic growth on income inequality in the US", Journal of Macroeconomics, 45, 258-273 (2015).

8. N. L. P. Y Adipuryanti and I. K. Sudibia, "Analisis Pengaruh Jumlah Penduduk yang Bekerja dan Investasi Terhadap Ketimpangan Distribusi Pendapatan Melalui Pertumbuhan Ekonomi Kabupaten/Kota di Provinsi Bali", Piramida Vol. XI No. 1: 20 - 28 (2015).

9. A. Pauzi and D. N. Budiana, "Faktor-Faktor Yang Mempengaruhi Secara Langsung Maupun Tidak Langsung Ketimpangan Distribusi Pendapatan Provinsi Bali”, E-Jurnal Ekonomi Pembangunan Universitas Udayana, 5(6) (2016).

10. V. Bantika, O. L. Benu, and G. H. Kapantow, "Faktor-Faktor Yang Mempengaruhi Ketimpangan Distribusi Pendapatan Di Sulawesi Utara", COCOS (Vol. 6, No. 17) (2015).

11. K. Sylwester, "Income inequality and population density 1500 AD: a connection", Journal of Economic Development, 28(2), 61-82 (2003).

12. S. N. Sungkar, Nazamuddin, M. Nasir, "Pengaruh Upah Minimum Terhadap Ketimpangan Pendapatan di Indonesia”, Jurnal Ilmu Ekonomi: Program Pascasarjana Unsyiah, 3(2) (2015).

13. C. Lin, \& M. S. Yun, "The effects of the minimum wage on earnings inequality: evidence from China", In Income Inequality Around the World (pp. 179-212), Emerald Group Publishing Limited (2016).

14. B. S. Litwin, "Determining the Effect of the Minimum Wage on Income Inequality", Student Publications. 300, Retrieved from http://cupola.gettysburg.edu/student_scholarship 1300 in October 5, 2017(2015).

15. N. D. Gujarati, and C. P. Dawn, "Dasar-dasar Ekonometrika”, Salemba Empat, Jakarta (2012).

16. Badan pusat statistik, "Statistics Indonesia", Retrieved from https://www.bps.go.id/l on September 6, (2017). 